\title{
ITSN1 and Ruk/CIN85 colocalized to clathrin-coated pits in MCF-7 cells
}

\author{
O. V. Nikolaienko, I. Ya. Skrypkina, L. O. Tsyba, L. B. Drobot', A. V. Rynditch
}

Institute of Molecular Biology and Genetics NAS of Ukraine

150, Zabolotnogo Str., Kyiv, Ukraine, 03680

${ }^{1}$ Palladin Institute of Biochemistry NAS of Ukraine

9, Leontovycha Str., Kyiv, Ukraine, 01601

rynditch@imbg.org.ua

\begin{abstract}
Aim. Activation of receptor tyrosine kinases (RTK) by corresponding ligands results not only in signal propagation, but also initiates a number of processes, such as clathrin-mediated endocytosis, which precisely regulate biological outcome. These processes are tightly controlled by coordinated action of a plethora of proteins - enzymes, scaffolds and inhibitory molecules. An example of an endocytic accessory protein that also functions in cell signaling is provided by intersectin 1 (ITSN1). Previously we have shown that ITSN1 forms a complex with adaptor protein Ruk/CIN85 and ubiquitin ligase Cbl-b, which are implicated in down regulation of RTK. The present study aimed to determine the subcellular localization of ITSN1-Ruk/CIN85 complexes relatively to clathrin light chain and Cbl-b. Methods. Transient transfection of MCF-7 breast adenocarcinoma cells with the constructs containing Omni-tagged intersectin 1 and clathrin light chain fused with mCherry fluorescent protein was utilized to determine subcellular localization by direct or indirect immunofluorescence. Results. We found that Ruk/CIN85-ITSN1 complexes partially colocalized with Cbl-b and clathrin light chain in MCF-7 cells. Conclusions. In our report we provide experimental evidence that ITSN1-Ruk/CIN85 complexes exist in pre-assembled state with Cbl-b and are targeted to clathrin-coated pits in MCF-7 cells.
\end{abstract}

Keywords: intersectin, Ruk/CIN85, Cbl-b, clathrin-coated pits, immunofluorescence.

Introduction. Intersectin 1 (ITSN1) is an evolutionary conserved adaptor protein involved in the regulation of multiple cellular processes [1-4]. Its ubiquitous isoform comprises two N-terminal Eps15 homology domains (EH1 and EH2), a central coiled-coil region (CCR) and five tandem Src homology domains (SH3 A-E). By these domains ITSN1 was shown to bind different endocytic proteins such as dynamin, epsin, Eps 15, synaptojanin 1, etc. (for review, see [5]). As any other endocytic scaffolds, ITSN1 is also tightly linked to both signal propagation and its attenuation. Mo-

(C) Institute of Molecular Biology and Genetics NAS of Ukraine, 2009 reover, it is known that ITSN1 can directly interact with MAPK cascade member Sos 1 and ubiquitin protein ligases c-Cbl and Cbl-b [6-8]. Recently, we have found that ITSN1 forms a complex with another signal attenuator, adaptor protein Ruk/CIN85 [5]. Furthermore, we have shown that Ruk/CIN85, c-Cbl and ITSN1 colocalize in small $(d=\sim 0.2-0.3 \mu \mathrm{m})$ structures close to plasma membrane. In this report, we describe localization pattern of Cbl-b and ITSN1Ruk/CIN85 complexes in MCF-7 cells and provide evidence that ITSN1-Ruk/CIN85-rich structures contain clathrin, and thus they may correspond to clathrin-coated pits (CCPs). 
Materials and Methods. Antibodies. A monoclonal anti-Omni (D-8): sc-7270, polyclonal anti-Omni (M-21): sc-499 and polyclonal anti-Cbl-b (H-454): sc-1705 antibodies were purchased from Santa Cruz Biotechnology. For immunofluorescence, Alexa Fluor 405 goat anti-rabbit IgG (Invitrogen) and Texas Red horse anti-mouse IgG (Vector Laboratories Inc.) antibodies were used.

Plasmid construction. The Omni epitope-tagged ITSN1 construct was described previously [5]. Plasmid containing mCherry-tagged clathrin light chain (pmCherry-CLC) was constructed using vector pEGFP-CLC kindly provided by Dr. Havrylov, Poland.

Cell culture and transfection. The human breast adenocarcinoma (MCF-7) cells stably overexpressing GFP-fused Ruk/CIN85 (Drobot L., manuscript in preparation) were grown on coverslips at $37{ }^{\circ} \mathrm{C}$ in $5 \%$ $\mathrm{CO}_{2}$ in Dulbecco's modified Eagle's medium with high glucose content, $10 \%$ fetal bovine serum, $2 \mathrm{mM}$ glutamine, $50 \mathrm{U} / \mathrm{ml}$ penicillin and $100 \mu \mathrm{g} / \mathrm{ml}$ streptomycin. Cells were transfected using polyethyleneimine (JetPEI, Polyplus Transfection) and processed $18 \mathrm{~h}$ after transfection.

Immunofluorescence and confocal microscopy. Transfected cells were washed in cold PBS, fixed in $4 \%$ formaldehyde for $15 \mathrm{~min}$, washed three times for 5 min each with PBS containing $0.2 \%$ Triton X-100 and blocked with blocking buffer ( $2 \%$ bovine serum albumine, $0.2 \%$ Triton X-100 in PBS) for $30 \mathrm{~min}$ at room temperature. Incubations were performed at room temperature with antibodies diluted in blocking buffer. Slides were mounted using PVA-DABCO (Fluka) and images were captured with a Leica TSC SPE or Zeiss LSM 510 Meta confocal microscopes. All images represent a single confocal section, taken from the bottom surface of expressing cells.

Results and Discussion. Clathrin-mediated endocytosis (CME) is the major mechanism of protein internalization in eukaryotic cell. While endocytosis was traditionally considered as a negative regulatory mechanism for activated RTKs, it is now clear that positive signalling requires endocytosis as well. During CME, receptors and their ligands are recruited into clathrin-coated vesicles (CCVs) that are formed at the plasma membrane in active sites called clathrin- coated pits (CCPs). This process is facilitated by adaptor proteins which interact directly or indirectly with both cytosolic domains of receptors and clathrin.

It was shown that intersectin 1 localizes to perinuclear compartment and clathrin-coated pits of endothelial and neuronal cells $[9,10]$. In turn, Ruk/CIN85 was found at COPI-coated vesicles in Golgi $[11,12]$. To determine whether ITSN1 and Ruk/CIN85 localize within CCPs we analyzed the subcellular distribution of these proteins in cells relatively to clathrin light chain (CLC) - the central component of CCPs and CCVs. MCF-7 cells stably overexpressing full-length GFP-tagged Ruk/CIN85 were transiently transfected with expression constructs encoding Omni-ITSN1 and mCherry-tagged clathrin light chain (mCherry-CLC). Immunofluorescence analysis revealed that GFP-Ruk/ CIN85 and Omni-ITSN1 proteins colocalized and concentrated in the perinuclear region and in round juxtamembrane structures, which were also clathrinpositive (Fig. 1, see inset). Therefore, intersectin 1 and Ruk/CIN85 partially localize to clathrin-coated pits in MCF-7 cells.

It should also be noted that phenotype of MCF-7 cells stably overexpressing full-length GFP-tagged Ruk/CIN85 resembles that of brefeldin A-treated HeLa cells [13]: considerable number of cells contain Ruk/CIN85-positive prolonged membrane tubules (data not shown). This observation points to possible perturbations in the membrane trafficking and is consistent with a significant role of Ruk/CIN85 in Golgi-endoplasmic reticulum and intra-Golgi transport $[11,12]$.

Additionally, we examined the subcellular colocalization of ITSN1, Ruk/CIN85 and the ubiquitin ligase Cbl-b in MCF-7 cells. Cbl-b is known to interact with both ITSN1 and Ruk/CIN85 adaptor proteins: ITSN1 binds Cbl-b by its SH3 A and E domains [7], while Ruk/CIN85 interacts with an atypical proline-rich motif at the distal end of Cbl-b through SH3 domains [14, 15]. Immunofluorescent analysis revealed that Omni-ITSN1, GFP-Ruk/CIN85 and endogenous Cbl-b display moderate levels of colocalization in MCF-7 cells (Fig. 2, see inset).

Both ITSN1 and Ruk/CIN85 aid in assembling clathrin-coated vesicles through association with numerous endocytic proteins [5] and are presumed to 
link receptor endocytosis with cytoskeletal rearrangements $[4,16]$. It is widely accepted that numerous components of signal transduction cascades assemble at clathrin coated pits and remain associated during endocytosis. In our report we provide additional experimental evidence that supports this idea. However, determination of the exact composition of complexes and elucidation of their localization-critical components require additional experiments.

О. В. Ніколаєнко, І. Я. Скрипкіна, Л. О. Циба, Л. Б. Дробот, A. В. Риндич

Iнтерсектин 1 та Ruk/CIN85 колокалізуються в клатриноблямованих ямках клітин лінії MCF-7

Резюме

Мета. Активачія рецепторних тирозинкіназ відповідними лігандами призводить не лише до розповсюдження сигналу, але й ініиіює різні прочеси, серед яких клатрин-опосередкований ендоцитоз, щзо регулюють клітинну відповідь. Такі процеси чітко контролюються завдяки координованій дї великоӥ кількості білків - ферментів, адапторів та інгібіторів. Прикладом адапторного білка, щчо функиіонує як в ендоцитозі, так $i$ в клітинній сигналізації, є інтерсектин 1 (ITSN1). У попередніх дослідженнях ми показали, що ITSN1 утворює комплекс з адапторним білком Ruk/CIN85 ma убіквітинлігазою Cbl-b, які залучені до негативної регулячії рецепторних тирозинкіназ. Метою даної роботи було визначити субклітинну локалізацію комплексів Ruk/CIN85-ITSN1 по відноченню до клатрину та Cbl-b. Методи. Для встановлення локалізації білків клітини аденокарииноми молочної залози людини МСF-7 транзієнтно трансфікували конструкціями, щзо містять ITSN1 $і$ клатрин, та вивчали методами прямого і непрямого імунофлуоресцентного аналізу. Результати. Показано, щзо ITSN1 i Ruk/CIN85 частково колокалізуються з Cbl-b i клатрином у клітинах лінії MCF-7. Висновки. Продемонстровано, що комплекси Ruk/ CIN85 з ITSN1 колокалізуються з Cbl-b $i$ знаходяться у клатрин-облямованих ямках клітин лінії MCF-7.

Ключові слова: інтерсектин, Ruk/CIN85, Cbl-b, клатрин-облямовані ямки, імунофлуоресиенція.

\section{А. В. Николаенко, И. Я. Скрипкина, Л. А. Циба, Л. Б. Дробот, A. В. Рындич}

Интерсектин 1 и Ruk/CIN85 колокализуются в клатринокаймленных ямках клеток линии MCF-7

Резюме

Цель. Активация рецепторних тирозинкиназ соответствующчими лигандами приводит не только к распространению сигнала, но и иниииирует разные процессы, например, клатринопосредованный эндоцитоз, которые регулируют клеточный ответ. Эти процессы строго контролируются благодаря координированному действию большого количества белков ферментов, адапторов и ингибиторов. Примером адапторного белка, функиионирующего как в эндоцитозе, так и в клеточной сигнализачии, служит интерсектин 1 (ITSN1). Ранее нами показано, что ITSN1 формирует комплекс с адапторным бел- ком Ruk/CIN85 и убиквитинлигазой Cbl-b, участвующими в негативной регуляции рецепторных тирозинкиназ. Целью данной работы было выявление субклеточной локализации комплексов Ruk/CIN85-ITSN1 по отношению к клатрину и Cbl-b. Meтоды. Для определения локализачии белков клетки аденокарииномы молочной железы человека МCF-7 транзиентно трансфицировали конструкциями, кодирующими ITSN1 и клатрин, и исследовали методами прямого и непрямого иммунофлуоресиентного анализа. Результаты. Показано, что ITSN1 и Ruk/ CIN85 частично колокализуются с Cbl-b и клатрином в клетках линии MCF-7. Выводы. Установлено, что комплексы ITSN1 u белка Ruk/CIN85 частично колокализуются c Cbl-b и находятся в клатрин-окаймленных ямках клеток линии MCF-7.

Ключевые слова: интерсектин, Ruk/CIN85, Cbl-b, клатринокаймленные ямки, иммунофлуоресиенция.

\section{REFERENCES}

1. Sengar A., Wang W., Bishay J., Cohen S., Egan S. The EH and $\mathrm{SH} 3$ domain Ese proteins regulate endocytosis by linking to dynamin and Eps15 // EMBO J.-1999.-18, N 5.-P. 11591171.

2. Predescu S., Predescu D., Knezevic I., Klein I., Malik A. Intersectin-1s regulates the mitochondrial apoptotic pathway in endothelial cells // J. Biol. Chem.-2007.-282, N 23.P. 17166-17178.

3. Mohney R., Das M., Bivona T., Hanes R., Adams A., Philips M., O'Bryan $J$. Intersectin activates Ras but stimulates transcription through an independent pathway involving JNK // J. Biol. Chem.-2003.-278, N 47.-P. 47038-47045.

4. Hussain N., Jenna S., Glogauer M., Quinn C., Wasiak S., Guipponi M., Antonarakis S., Kay B., Stossel T., LamarcheVane N., McPherson P. Endocytic protein intersectin-1 regulates actin assembly via Cdc42 and N-WASP // Nat. Cell Biol.-2001.-3, N 10.-P. 927-932.

5. Nikolaienko O., Skrypkina I., Tsyba L., Fedyshyn Y., Morderer D., Buchman V., de la Luna S., Drobot L., Rynditch A. Intersectin 1 forms a complex with adaptor protein Ruk/CIN85 in vivo independently of epidermal growth factor stimulation // Cell. Signal.-2009.-21, N 5.-P. 753-759.

6. Tong X., Hussain N., de Heuvel E., Kurakin A., Abi-Jaoude E., Quinn C., Olson M., Marais R., Baranes D., Kay B., McPherson $P$. The endocytic protein intersectin is a major binding partner for the Ras exchange factor mSos 1 in rat brain // EMBO J.-2000.-19, N 6.-P. 1263-1271.

7. Nikolaienko O., Skrypkina I., Dergay O., Matskova L., Tsyba L., Dergay M., Kropyvko S., Vingberg G., Rynditch A. Cbl family proteins - new partners of intersectin 1 // Collection of scientific papers «Factors of experimental evolution of organisms».-Kyiv: Logos, 2006.-Vol. 3.-P. 122-127.

8. Martin N., Mohney R., Dunn S., Das M., Scappini E., O'Bryan $J$. Intersectin regulates epidermal growth factor receptor endocytosis, ubiquitylation, and signaling // Mol. Pharmacol.-2006.-70, N 5.-P. 1643-1653.

9. Hussain N., Yamabhai M., Ramjaun A., Guyi A., Baranesi D., O'Bryan J., Der C., Kay B., McPherson P. Splice variants of intersectin are components of the endocytic machinery in neurons and nonneuronal cells // J. Biol. Chem.-1999.-274, N 22.-P. 15671-15677.

10. Thomas S., Ritter B., Verbich D., Sanson C., Bourbonniere L., McKinney R., McPherson P. Intersectin regulates dendritic spine development and somatodendritic endocytosis but 
not synaptic vesicle recycling in hippocampal neurons // J. Biol. Chem.-2009.-284, N 18.-P. 12410-12419.

11. Havrylov S., Ichioka F., Powell K., Borthwick E., Baranska J., Maki M., Buchman V. Adaptor protein Ruk/CIN85 is associated with a subset of COPI-coated membranes of the Golgi complex // Traffic.-2008.-9, N 5.-P. 798-812.

12. Zhang J., Zheng X., Yang X., Liao K. CIN85 associates with endosomal membrane and binds phosphatidic acid // Cell Res.-2009.-19, N 6.-P. 733-746.

13. Sciaky N., Presley J., Smith C., Zaal K., Cole N., Moreira J., Terasaki M., Siggia E., Lippincott-Schwartz J. Golgi tubule traffic and the effects of brefeldin A visualized in living cells // J. Cell Biol.-1997.-139, N 5.-P. 1137-1155.

14. Szymkiewicz I., Kowanetz K., Soubeyran P., Dinarina A., Lipkowitz S., Dikic I. CIN85 participates in Cbl-b-mediated down-regulation of receptor tyrosine kinases // J. Biol. Chem.-2002.-277, N 42.-P. 39666-39672.

15. Kowanetz K., Szymkiewicz I., Haglund K., Kowanetz M., Husnjak K., Taylor J., Soubeyran P., Engstrom U., Ladbury $J$., Dikic I. Identification of a novel proline-arginine motif involved in CIN85-dependent clustering of $\mathrm{Cbl}$ and downregulation of epidermal growth factor receptors // J. Biol. Chem.-2003.-278, N 41.-P. 39735-39746.

16. Dikic I. CIN85/CMS family of adaptor molecules // FEBS Lett.-2002.-529, N 1.-P. 110-115.

УДК 577.25

Надійшла до редакції 10.07.09 
Рисунки до статті О. В. Ніколаєнко та співавт.
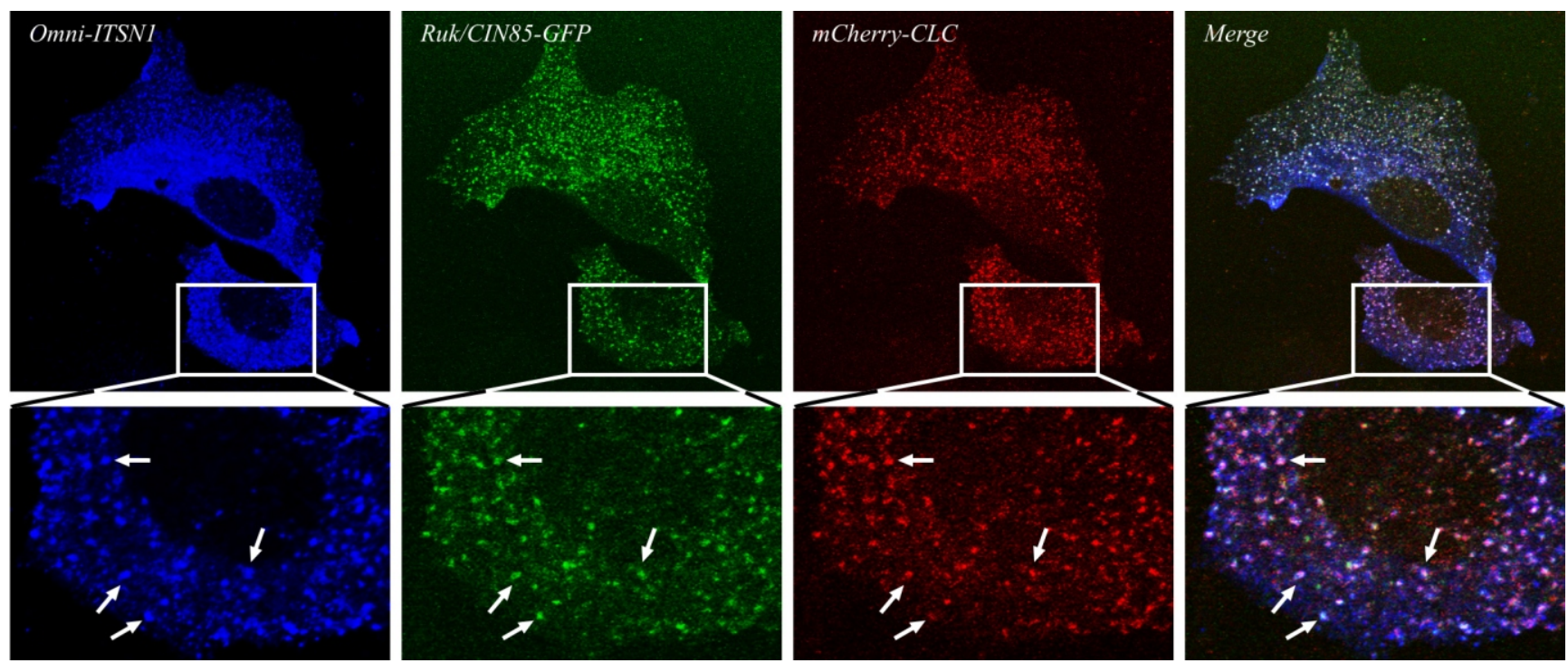

Fig. 1. ITSN1 colocalizes with Ruk/CIN85 and clathrin light chain in MCF-7 cells. MCF-7 cells stably overexpressing GFP-tagged Ruk/CIN85 were transfected with Omni-ITSN1-s and mCherry-CLC. ITSN1 protein was localized by indirect immunofluorescence with anti-Omni antibodies followed by secondary antibodies coupled to Alexa Fluor 405 (blue). White arrows indicate some of structures labelled by all three proteins
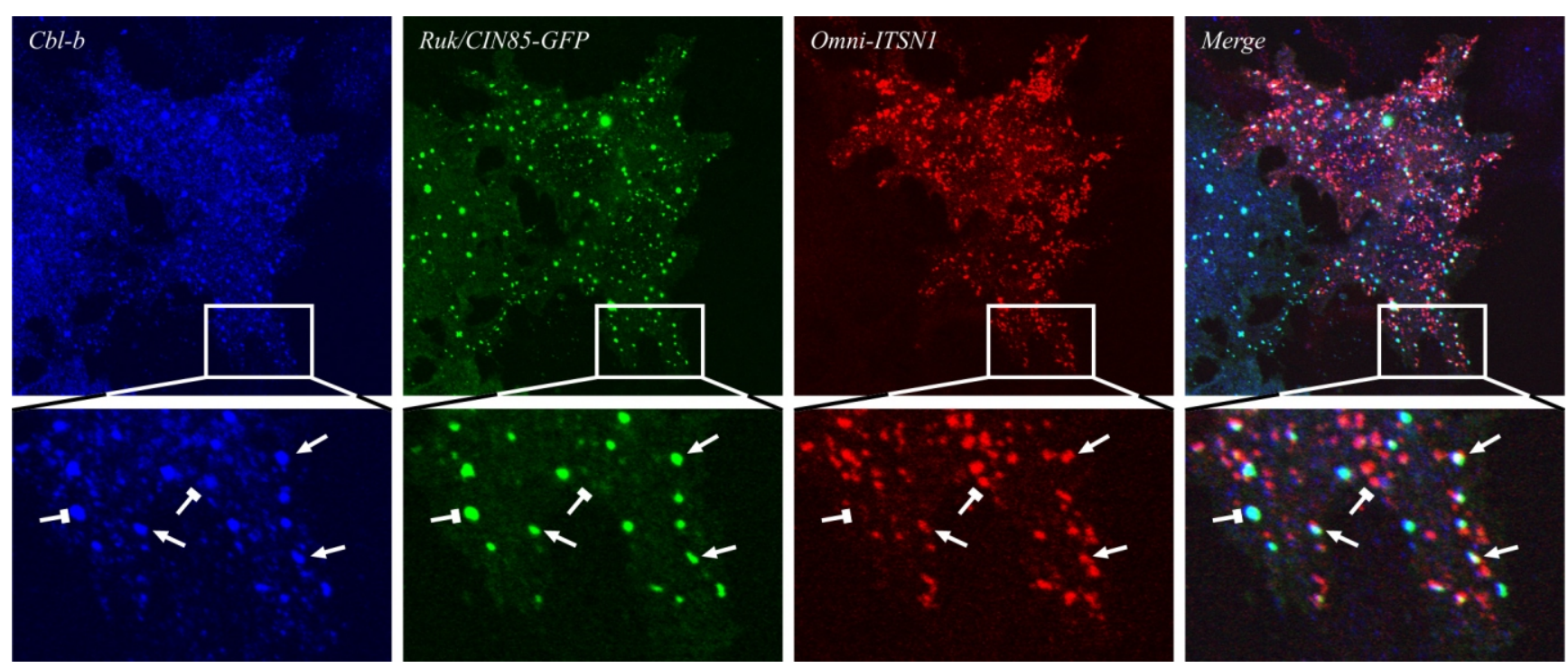

Fig. 2. ITSN1 colocalizes with Ruk/CIN85 and Cbl-b in MCF-7 cells. MCF-7 cells stably overexpressing GFP-tagged Ruk/CIN85 were transfected with Omni-ITSN1-s and double-stained with antibodies against Omni-tag (visualized with Texas Red-conjugated anti-mouse $\mathrm{IgG}$ ) and endogenous Cbl-b (visualized with Alexa Fluor 405-conjugated anti-rabbit IgG). White arrows indicate some of structures that are positive for all three proteins. Blunt white arrows indicate structures negative for at least one of the proteins 